\begin{abstract}
Iranica
Abstracta Iranica Revue bibliographique pour le domaine irano-aryen

Volume 40-41 | 2019

Comptes rendus des publications de 2017-2018
\end{abstract}

\title{
Rahim Shayegan (ed.). Cyrus the Great. Life and Lore
}

\section{Reinhard Pirngruber}

\section{OpenEdition}

\section{Journals}

Electronic version

URL: http://journals.openedition.org/abstractairanica/50066

DOI: 10.4000/abstractairanica.50066

ISBN: 1961-960X

ISSN: 1961-960X

Publisher:

CNRS (UMR 7528 Mondes iraniens et indiens), Éditions de l'IFRI

Electronic reference

Reinhard Pirngruber, "Rahim Shayegan (ed.). Cyrus the Great. Life and Lore", Abstracta Iranica [Online], Volume 40-41 | 2019, document 85, Online since 30 December 2019, connection on 22 April 2021.

URL: http://journals.openedition.org/abstractairanica/50066 ; DOI: https://doi.org/10.4000/ abstractairanica. 50066

This text was automatically generated on 22 April 2021.

Tous droits réservés 


\title{
Rahim Shayegan (ed.). Cyrus the Great. Life and Lore
}

\author{
Reinhard Pirngruber
}

\section{REFERENCES}

Rahim Shayegan (ed.). Cyrus the Great. Life and Lore. (Ilex Foundation Series 21)

Cambridge: MA \& London, Harvard University Press, 2018, p. vii+258

1 As indicated by the title, this volume collects fourteen essays (plus one introduction) dedicated to the Achaemenid king Cyrus II the Great, arranged roughly in a chronological order. Two aspects are particularly focussed on, the first being texts promulgated during Cyrus' reign and the second representations of Cyrus in various later texts, including Greek historiographers and Persian writings such as the Šăhnāme.

- Hanspeter Schaudig, "The text of the Cyrus Cylinder" (p.16-25)

3 H. Schaudig is the only author with two contributions to this volume. In the first chapter, he provides Akkadian text and an English translation of the Cyrus Cylinder.

4 - Matt Waters, "Cyrus rising: Reflections on word choice, ancient and modern" (p. 26-45)

5 This essay deals with the difficulty of translating key terms in Cyrus's inscriptions (e.g. his designation as ardu sehru, "young" or "insignificant" servant of Marduk) and discusses Cyrus' choice of royal titles, in particular the designation king of Anshan.

6 - David Stronach, "Cyrus, Anshan, and Assyria" (p. 46-66)

7 D. Stronach in his paper cautions against exaggerating the Elamite impact of the early Achaemenid Empire, locating the short-lived use of the title king of Anshan in a Babylonian context. Instead, he points to the relevance of Assyrian influence during the formative phase of the Achaemenid Empire, discernible e.g. in the remains from Pasargadae. 

influencing the Cyrus Cylinder. Rather the confining himself to the genre of royal inscriptions, where mostly superficial analogies are a given, he demonstrates numerous allusions to the Babylonian Epic of Creation (enūma eliš) as well as conceptual correspondences to the pseudo-historiographical Esangila Chronicle.

10 - Beate Pongratz-Leisten, “"Ich bin ein Babylonier”: The political-religious message of the Cyrus Cylinder" (p.92-105)

11 This essay deals with the religious-ideological dimensions of the Cyrus Cylinder, focussing on the restoration of the privileged statuses (kidinnu) of the city of Babylon and its citizens emphasized in the text and royal participation in the Babylonian New Year's festival. societies, marked i.a. by demographic decline, absence of monumental construction and the recasting of the past as a Golden Age, to the province of Judah during the sixth century BCE. He further addresses Cyrus' role in the return of the Jews from their exile according to the priestly literature.

- Marvin A. Sweeney, "Contrasting portrayals of the Achaemenid monarchy in Isaiah and Zecharia” (p. 117-130)

15 This contribution shows that there were different perceptions of the Achaemenids in the old Testament. The rather hostile attitude prevailing in the books of the Twelve Prophets (such as Haggai and Zechariah), calling for the restoration of the Davidic monarchy, provide a counterpoint to the favourable judgments in (Second) Isaiah, Ezra, and Chronicles, where Cyrus acts as YHWH's chosen one.

16 - Rémy Boucharlat, "Cyrus and Pasargadae. Forging an empire - fashioning "paradise"” (p. 131-149)

17 The A. provides a succinct summary of recent research carried out on Cyrus's building work in Pasargadae, focussing on novel elements in the regions both in iconography and technological aspects, e.g. stone-cutting techniques. Particular attention is paid to the sophisticated hydraulic infrastructure, unprecedented in the area.

18 - David Beckman, "Cyrus the Great and ancient propaganda" (p. 150-169)

19 The article by D. Beckman focuses on the birth narrative of Cyrus as transmitted by several Greek historiographers. After an introduction detailing his theoretical framework grounded in studies of propaganda, he identifies the target audiences for the respective versions of the story in Herodotus, Xenophon and Ctesias.

20 - Maria Brosius: “Cyrus the Great: a hero's tale” (p. 170-182)

21 M. Brosius looks at Cyrus as an archetypical hero figure, pointing out similarities with the 'biography' of the contemporary literary and movie character Jason Bourne. The focal points in her paper are Cyrus' origins and identity, his accession to the throne as well as his political, diplomatic and military skills.

22 - Jason M. Schlude: "Cyrus the Great and Roman views of Ancient Iran" (p. 183-195) 

According to the A., the mostly favourable depictions - in particular, writings of Cicero receive much attention - have broader ramifications: They are said pave the way for a more nuanced assessment of the Parthians, considered heirs of the Achaemenids, in Roman historiography, who are often reduced by contemporary scholarship to a negative 'imperial other'.

- Marek J. Olbrycht: "The shaping of political memory: Cyrus and the Achaemenids in royal ideologies of the Seleucid and Parthian periods" (p. 198-220)

The central interest of this contribution is the adoption of Achaemenid elements as well as the use of the dynasty in legitimizing strategies by successive empires. The latter aspect is especially current in the petty kingdoms of Asia Minor - especially by means of creating (fictitious) genealogical ties - whereas the Parthian mostly referred back to their own dynasty founder Arsaces. One prominent example of the former is the use of the title 'king of kings' by the Arsacids after their conquest of Media; in the A.'s view, this region acted as intermediary of sorts connecting Achaemenids and Arsacids.

26 - Touraj Daryaee, "On forgetting Cyrus and remembering the Achaemenids in late antique Iran" (p. 221-231)

The A. contrasts the rather vivid remembrance of Cyrus by Jewish and Armenian communities in the Middle Persian period with the remarkable absence of references to Cyrus and the Achaemenids (and the Parthians) in Middle Persian literature. The reason for this is sought in the peculiarities of the nascent historiography of that period, heavily indebted to the Avesta.

28 - Olga M. Davidson: "Traces of poetic traditions about Cyrus the Great and his dynasty in the Šăhnāme of Ferdowsi and the Cyrus Cylinder" (p. 232-241)

29 The final contribution identifies motives in Ferdowsi's Šāhnāme possibly also present in Achaemenid period texts, including two inscriptions by Xerxes as well as the Cyrus cylinder. In particular, the respective depictions of Cyrus and Key Khosrow as restorers of the religious order and their drafting of messages to the divine and to posteriority the Cyrus cylinder itself, in case of the former - are stressed.

\section{AUTHORS}

\section{REINHARD PIRNGRUBER}

Institut für Orientalistik, Wien 